\title{
EVALUATION OF METEOROLOGICAL ELEMENTS AND LETTUCE (Lactuca sativa, L.) YIELD RELATED TO GEOGRAPHIC ORIENTATION OF POLYETHYLENE GREENHOUSES
}

\author{
Cláudio Márcio Pereira de Souza \\ Antonio Evaldo Klar* \\ Department of Agricultural Engineering, College of Agricultural Sciences, State University of São \\ Paulo, P.O. 237, CEP 18603-970, Botucatu-SP. E-mail: cmpsouza@fca.unesp.br \\ * Scientific Researcher of CNPq \\ Luiza Helena Duenhas \\ EMBRAPA Semi Árido, P.O. 23, CEP 56300-970, Petrolina-PE.
}

\begin{abstract}
1 ABSTRACT
This experiment was carried out at the Agricultural Engineering Department, FCA/UNESP, BotucatuSP aiming to study the geographic orientation influence of two plastic tunnels (East/West and North/South based on the magnetic North) on lettuce plant (Lactuca sativa L, cv. Elisa) behavior and on the evaporation distribution uniformity inside the tunnels. The plants were sowed on $05 / 05 / 1999$, transplanted on $05 / 29 / 1999$ and harvested on $06 / 31 / 1999$. Tensiometers were used to monitore soil water potentials. A drip irrigation system was used. Both tunnels received A Class pan and thermohygrographes in the center and $3 \mathrm{~m}$ apart small evaporimeters set at 3 heights $(0.50 \mathrm{~m}, 1.00 \mathrm{~m}$ and $1.50 \mathrm{~m}$ ). Through geostatistical analysis, there was not neither spatial dependency nor spatial variability of evaporation in both tunnels. However, the height of evaporimeters showed statistical differences: the $1.50 \mathrm{~m}$ height evaporimeter had slower evaporation than those from other heights. The air temperature, relative humidity and vapor pressure deficit averages were not statistically significant in both greenhouses when they were compared to those from the outside. A Class pan evaporation values were higher outside the tunnels than inside them, but there were no differences between both tunnels for this variable. The lettuce plant yield was not influenced by tunnel orientation, but there were significant differences on plant yield among beds inside each tunnel.
\end{abstract}

KEYWORDS: evaporation, irrigation, greenhouse.

\author{
SOUZA, C. M. P., KLAR, A. E., DUENHAS, L. H. AVALIAÇÃO DE ELEMENTOS \\ METEOROLÓGICOS E PRODUÇÃO DE ALFACE (Lactuca sativa L.) AFETADOS PELA \\ ORIENTAÇÃO GEOGRÁFICA DE ESTUFAS DE POLIETILENO.
}

\section{RESUMO}

O experimento foi realizado na área experimental do Departamento de Engenharia Rural da Faculdade de Ciências Agronômicas - Unesp/Botucatu, Estado de São Paulo, em duas estufas dispostas em 
diferentes orientações geográficas, Leste/Oeste e Norte/Sul. A alface (Lactuva sativa L.) cv. Elisa foi cultivada em ambas estufas, sendo semeada em 05/05/99, transplantada em 29/05/99 e colhida em 31/06/99. Utilizou-se tensiômetros para monitorar o potencial de água no solo para realizar o manejo do sistema de irrigação por gotejamento. Microevaporímetros eqüidistantes de $3 \mathrm{~m}$ e colocados em 3 alturas, $0.50,1.00$ e $1.50 \mathrm{~m}$, termohigrógrafos e tanques Classe " $\mathrm{A}$ " foram instalados nas duas estufas. Através de análise geoestatística, não se observou dependência espacial nem variabilidade espacial da evaporação nas duas estufas. Entretanto, a altura dos evaporímetros apresentou diferenças significativas: a evaporação à altura de 1.50 foi menor que nas outras duas.As médias de temperatura, umidade relativa e déficit de pressão de vapor do arnão diferiram estatisticamente entre as estufas e o ambiente externo. Os valores médios de evaporação de água no tanque Classe "A" instalado fora das estufas diferiram estatisticamente quando comparados com os instalados no interior das estufas, porém, entre as orientações não se constatou diferença significativa. Pôde-se verificar que não houve diferença significativa das características agronômicas da alface em ambas orientações estudadas. No entanto, houve diferença significativa para essas características entre os canteiros no interior das mesmas, havendo variância espacial para os dados de matéria fresca apenas na estufa N/S.

UNITERMOS: evaporação, irrigação, estufa.

\section{INTRODUCTION}

The production of vegetables in a closed system is undergoing great transformation in the search for modernization that give room for improved yield and consequently, the presence of farmers in the activity of which requires great effort in the direction of identifying and eliminating the technological shortcomings.

The knowledge of the correct time to apply irrigation and the quantity of water required for crops are of great importance for the suitable management in the closed system.

The utilization of greenhouses, mainly for cultivation of vegetables and ornamental plants, increased in the last five years in different regions of the country. The advantages of using this closed and semi-closed systems are many, for example, it can reduce the climatic hazards.

The use of plastic greenhouses is on the increase in the modern agriculture and is an important tool for increasing crop yields.

Several growers and researchers have studied and proposed studies to adjust environmental water to the demand of a lettuce crop. But in all these approaches the input water quantities received and the characteristics of soil and crop stand are always considered uniform within a plot. But the spatial variability of the amount of water received by the plants can be very large; the environmental non-uniformity is doubtless even more pronounced in greenhouses. In contrary to lack of water, which promotes water stress affecting lettuce yield, the high water application more than required affects drainage with fertilizer loss and consequently salinity rise.

Environmental conditions in greenhouse are often not uniform and rarely taken into account in researches that involve factors determining crop yields and quality. There have been many studies of the factors involving meteorological features in closed environments, but most do not fully integrate the nonuniformity of the system in consideration, because it is difficult to characterize the ranges, even though it is known that conditions can vary widely in the greenhouse.

Plastic tunnels in which the spatial distribution of incident radiation is uneven has been shown by experimental studies (KLAR \& BRAGA, 2000). The incident light varies mainly along a transverse gradient across the greenhouse, depending on the type of greenhouse, its orientation and type of covering material and weather conditions. The reflection of plastic coverture is resulted from the type and conditions of material, solar position and 
geographic bearing of the structure (KLAR \& ALVES, 1996). But, there are few studies about the distribution and spatial variability of micrometeorological features on different greenhouse types and their influence on plants.

According to Boulard et al. (1990), radiation balance is changed by plastic coverture, evaporation produces condensation and has direct influence on greenhouse microclimate. Several studies showed that the evapotranspiration in greenhouses is lower than outside, mainly due to wind reduction, radiation transmissivity decrease by plastic coverture and higher relative humidity (KLAR \& ALVES, 1996). These authors remarked that the evaporation values in greenhouses were significantly lower than those occurred outside and Teodoro et al. (1993) reached a value of $30 \%$. Both studies used the class A pan.

Evaporimeters are the cheapest and easiest method for measuring Reference Evapotranspiration (ETo), because evaporation involves the entire energetic complex responsible for water evaporation. However, evaporimeters are not frequently used in greenhouses, mostly the largest ones, as the class A pan, because of its possible influence on the environment (KLAR, 1988).

The higher plant growth and yield under greenhouse conditions have to consider two basic conditions: the best energy balance in relation to evapotranspiration and the correct plant water need application (MOSS et al., 1985).

The purpose of this study was to estimate the evaporation distribution and variability inside two plastic tunnel coordinates (North/South and East/West) and the minimum soil water potential for the best lettuce performance as well as to verify the variability and the spatial dependency of evaporation and, consequently, the energy distribution

\section{MATERIAL AND METHODS}

The experiment was conducted at the Agricultural Engineering Department, FCA/UNESP, Botucatu - SP, Latitude $22^{\circ} 51^{\prime}$ $\mathrm{S}$ and altitude $786 \mathrm{~m}$.

The soil was a silty clay loam, classified as a Ultisol; the bulk density was 1.45 to 1.48 g. $\mathrm{cm}^{-3}$ and the soil water characteristic curve was based on the 7 points per depth (Table 1). The chemical analysis, before the experiment was set up, is shown in the Table 2. The soil showed $1.3 \mathrm{dS} . \mathrm{m}^{-1}$ electric conductivity.

Table 1. Values of soil water potential $(\psi \mathrm{m})$ vs. soil water content ( $\theta$ volume basis) at $0-15$ and $15-30$ cm depths.

\begin{tabular}{cccccccc}
\hline$\psi \mathrm{m}(\mathrm{kPa})$ & -5 & -10 & -30 & -50 & -100 & -500 & -1500 \\
\hline$\theta(0-20 \mathrm{~cm})$ & 0.290 & 0.254 & 0.212 & 0.196 & 0.189 & 0.168 & 0.161 \\
$\theta(20-40 \mathrm{~cm})$ & 0.320 & 0.306 & 0.265 & 0.247 & 0.233 & 0.190 & 0.166 \\
\hline
\end{tabular}

Table 2. Chemical analysis of the soil before experiment installation.

\begin{tabular}{cccccccccccc}
\hline & $\mathrm{pH}$ & $\mathrm{OM}$ & $\mathrm{P}$ & $\mathrm{Al}$ & $\mathrm{H}+\mathrm{Al}$ & $\mathrm{K}$ & $\mathrm{Ca}$ & $\mathrm{Mg}$ & $\mathrm{SB}$ & $\mathrm{CTC}$ & $\mathrm{V} \%$ \\
\cline { 6 - 12 } & $\mathrm{CaCl}^{2}$ & $\mathrm{~g} . \mathrm{dm}^{-3}$ & resin & \multicolumn{7}{c}{$\mathrm{mmol.dm}^{-3}$} \\
EW0.20 & 5.7 & 16 & 70 & 5.7 & 24 & 2.6 & 31 & 17 & 50 & 74 & 68 \\
EW0.40 & 5.6 & 15 & 37 & 5.6 & 28 & 3.0 & 27 & 16 & 46 & 73 & 62 \\
NS0.20 & 5.9 & 14 & 119 & 5.9 & 24 & 2.7 & 32 & 13 & 47 & 71 & 67 \\
NS0.40 & 5.6 & 13 & 42 & 5.6 & 29 & 2.1 & 25 & 11 & 38 & 68 & 57 \\
\hline
\end{tabular}

EW and NS greenhouses directed East/West and North/South, respectively 0.20 and 0.40 are the soil depth (m) 
The climate of Botucatu region, according to Köepen, is mesotermic and humid; the rainfall and evapotranspiration average are $1516.8 \mathrm{~mm}$ and $692 \mathrm{~mm}$ per year, respectively. The annual mean temperature is $20.6{ }^{\circ} \mathrm{C}$, and the maximum and minimum temperatures are 23.5 and $17.4{ }^{\circ} \mathrm{C}$ respectively.

The dimensions of the two arched roof tunnels were $20 \mathrm{~m}$ length, $5 \mathrm{~m}$ width and $3.5 \mathrm{~m}$ height in the center, one was directed to North/South and other to East/West and covered with plastic material of $0.15 \mathrm{~mm}$ thickness. The lateral walls had $2 \mathrm{~m}$ height and were covered with "sombrite" screen curtains. Mobile plastic curtains were placed on the lateral walls only for use during heavy rainfall.

In order to estimate the soil water potential, tensiometers were installed at $0.15 \mathrm{~m}$ and $0.30 \mathrm{~m}$ depths. The soil water content was controlled by neutron probe. The irrigation system was done with "Queengil" drippers, with $1.4 \mathrm{~L}^{-1} \mathrm{~h}^{-1}$ per emitter, $70 \mathrm{kPa}$ pressure and $0.30 \mathrm{~m}$ interval and adjusted to the crop's evapotranspiration based on tensiometers and neutron probe measurements. The control system received: non return valve, air release valve, automatic metering valve, fertilizer tank through which the fertilizer solution was introduced into the system, grooved rings and sand filters and a pressure and flow regulators. The water distribution and uniformity of the irrigation system was previously evaluated, before the experiment was set up.

A thermohygrograph and a Class A pan were set up in the center of each tunnel. Climatic data outside the tunnels were obtained from automatic meteorological station about $400 \mathrm{~m}$ from the experiment.

72 small evaporimeters $(1.50 \mathrm{~L}$ volume, $0.07 \mathrm{~m}$ height and $0.18 \mathrm{~m}$ diameter) were located at three layers $(0.50,1.00$ and $1.50 \mathrm{~m}$ from the soil surface). The evaporimeter evaporations were measured three times a week. The spatial analysis of the data was appraised using Surfer software and analysis of variance was done using SIGMASTAT, SAS and Tukey Test.

Lettuce (Lactuca sativa L. cultivar Elisa) plants received fertilizers according to recommendations of van Raij et al. (1996). The lettuces (Lactuca sativa L. cv Elisa) were planted at a density of $0.30 \mathrm{~m} \times 0.30 \mathrm{~m}$ within the plants rows on 05/29/1999. 96 plants per greenhouse were collected, being 4 per point, around each evaporimeter set. Fresh and dry matters were measured. At harvest, each lettuce was identified according to its position, and weighed.

\section{RESULTS AND DISCUSSION}

\author{
5.1 Spatial Variability Analysis of Lettuce \\ Production
}

Spatial variability among the fresh weigh data in the North/South greenhouse, by variogram analysis, was dependent until $4.1 \mathrm{~m}$ (Figure 1 and 2). The Gaussian Model

showed the best adjustment with 13.000 Sill values and range 4.1 .

5.2 Geostatistical analysis of water evaporation from evaporimeters

The semivariogram analysis shows no spatial dependency among the observed data. They did not show increasing tendency ranges with the correspondent increase of the distance within the data. For this reason, the evaporation spatial variability in both greenhouses does not exist or the observation number was not enough. 


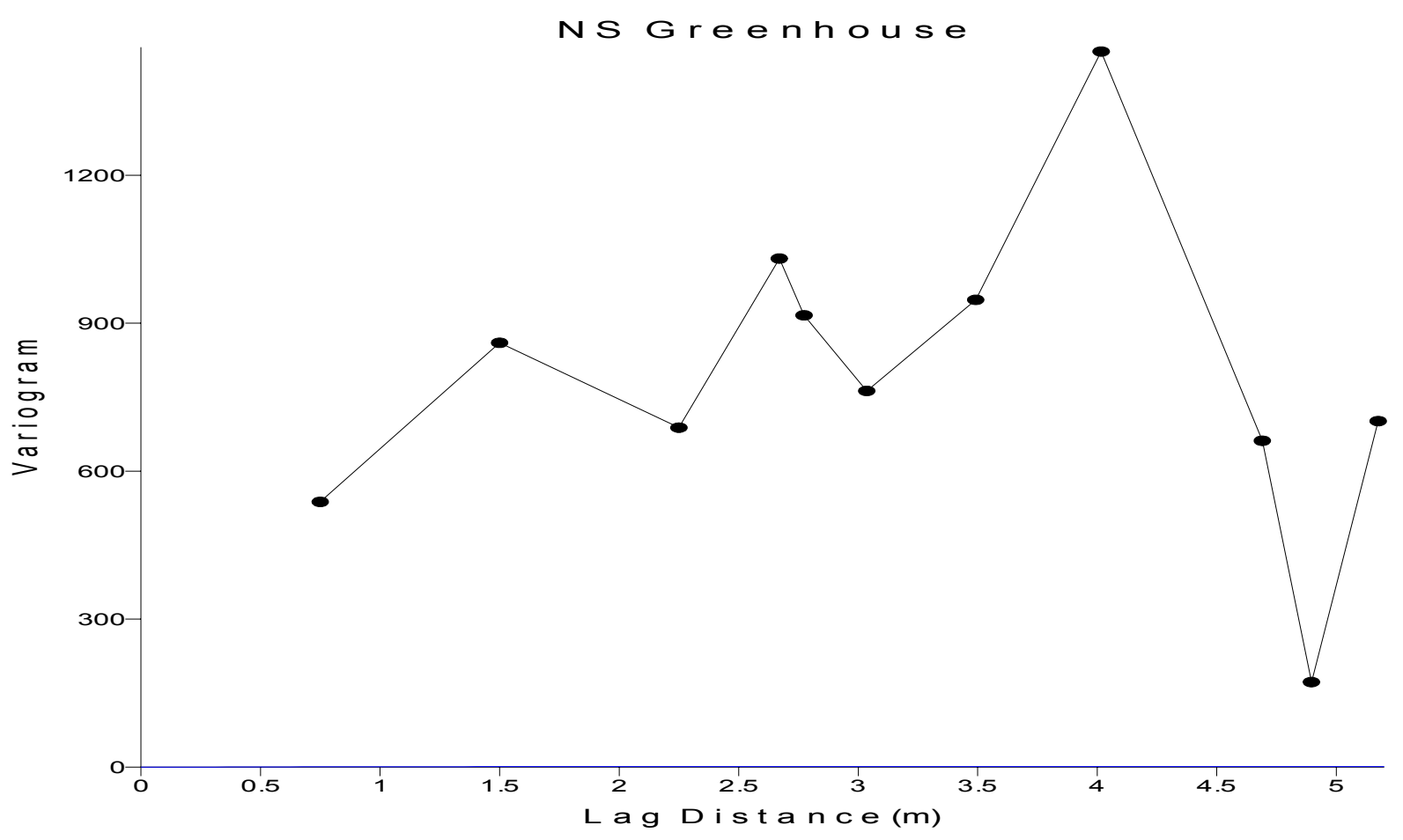

Figure 1. Semivariogram for fresh matter production for North/South greenhouse plants.

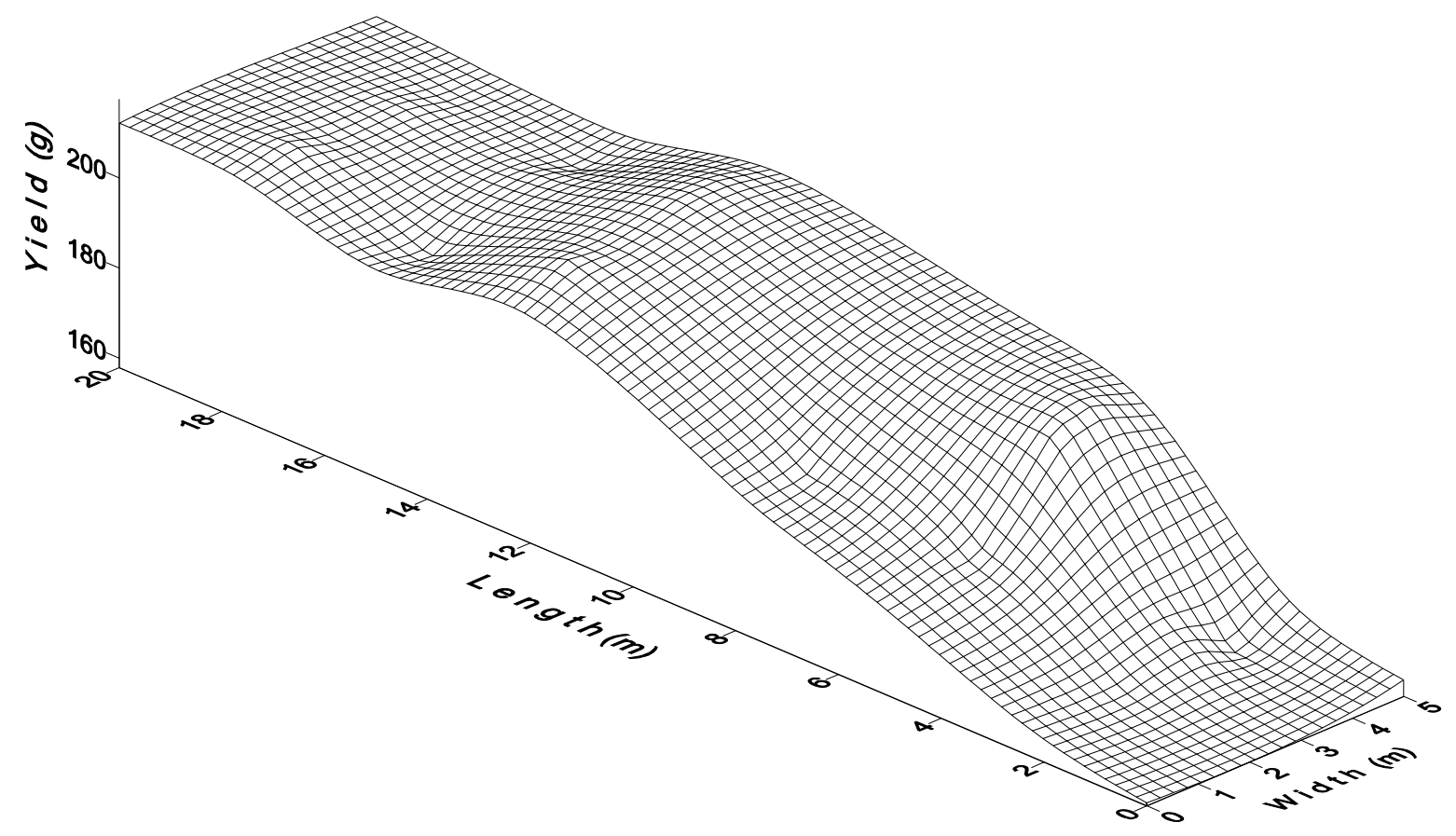

Figure 2. Gaussian Krigage for lettuce production in the greenhouse North/South 


\subsection{Air temperature and relative humidity}

The meteorological data (temperature, relative humidity, wind velocity, etc.) are affected by lack of rainfall, partial transmissivity of outside energy, mainly long and short waves radiation ranges inside greenhouses when compared to outside conditions. The Figure 3 and 4 show the average of minimum, medium and maximum air temperatures and relative humidities during the entire period of the experiment for the three environmental conditions: outside, East/West and North/South greenhouses without significant ranges within the three environments.

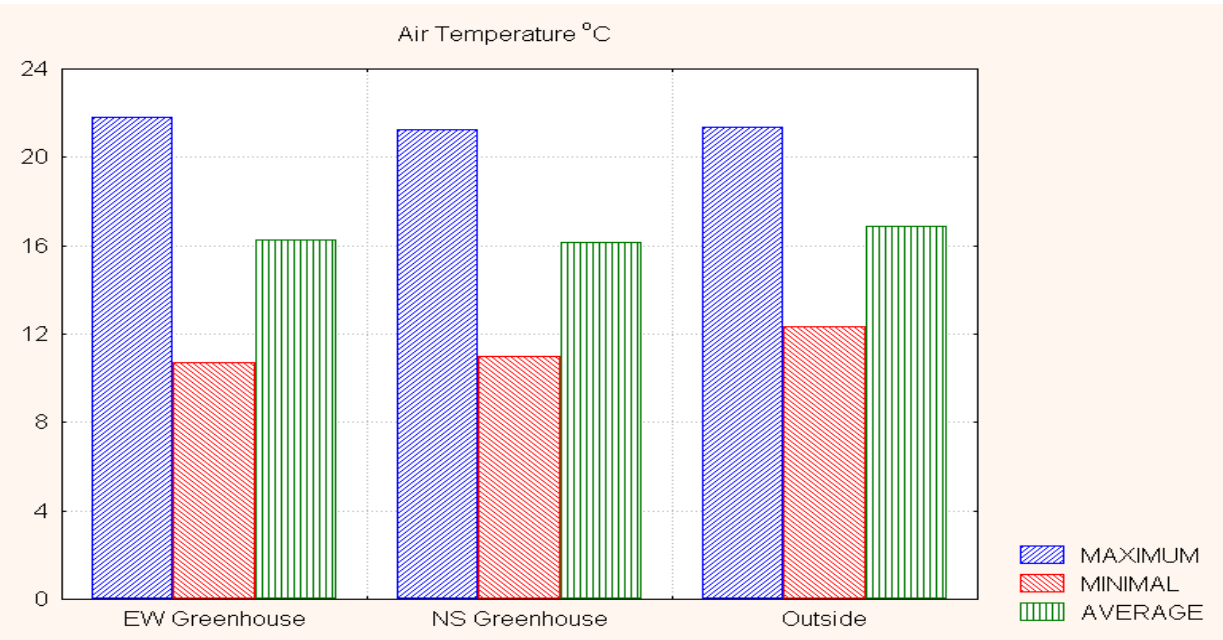

Figure 3. Temperature average from $\mathrm{E} / \mathrm{W}$ and $\mathrm{N} / \mathrm{S}$ greenhouses and outside environments.

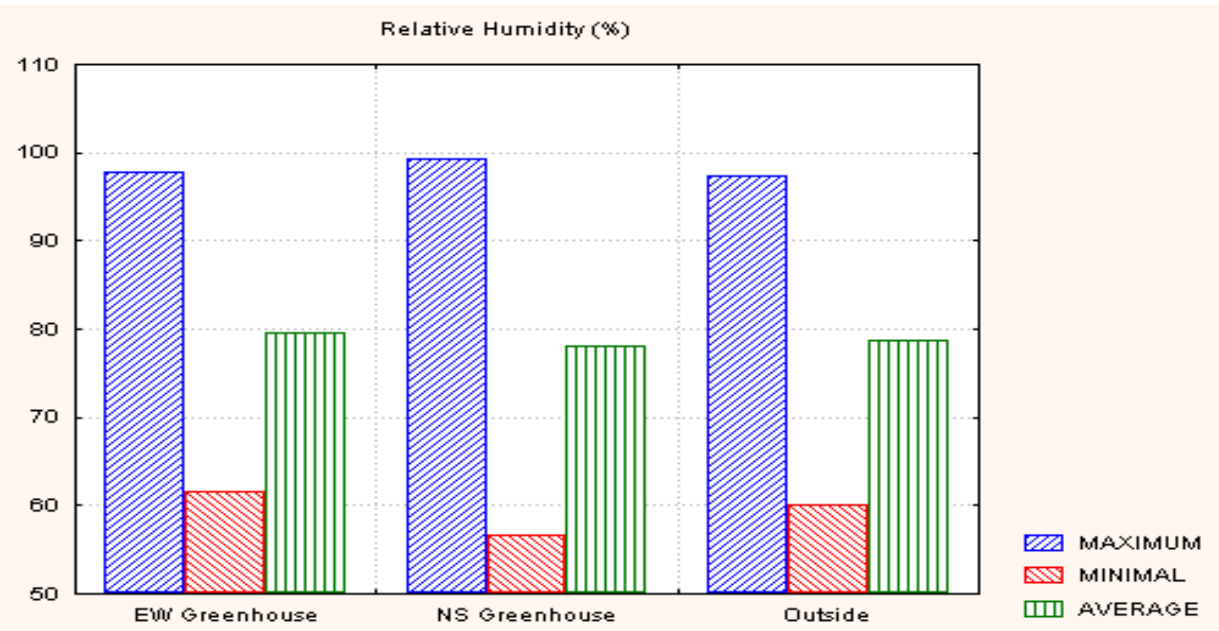

Figure 4. Relative humidity average from $\mathrm{E} / \mathrm{W}$ and N/S greenhouses and out side environments.

5.4 Evaporation from the evaporimeters

The evaporimeter heights affected the evaporation intensity. The evaporation values from the $1.5 \mathrm{~m}$ showed significantly less evaporation than the 0.5 and $1.0 \mathrm{~m}$ in both greenhouses (Fig. 5 and 6). Probably the difference comes from the soil temperature, 
higher near the soil surface than at the superior layers (KLAR, 1988).

The Table 3 shows significant differences among the four blocks in the greenhouses in relation to evaporation of the evaporimeters. However, there were not differences between greenhouses (Figure 5) for these evaporation values. These results do not agree with those obtained by Braga \& Klar (2000) which noted more uniform evaporation distribution in the East/West than in the North/South greenhouses. These differences can be as a result of the plants used: while lettuce was used in this experiment, pepper was utilized in the studies of other authors. Other possible explanation can be from the different period of the year used for both experiments. Other important conclusion is that the use of small evaporimeters is an important tool for evaluating meteorological conditions of greenhouses, because they integrate all the climatological features.

\subsection{Class A evaporation pan}

The Table 4 and the Fig 8 show higher Class A Pan evaporation values outside than inside greenhouse, but there was not significant differences between greenhouses for this variable. Several scientific papers showed that the temperatures inside greenhouses are higher than outside (KLAR \& BRAGA, 2000). Bourlard et al. (1990) affirm that evaporation produces condensation and affects the greenhouse climate. Other climate components influence the meteorological conditions inside greenhouses: wind velocity reduction, short wave radiation is decreased and the relative humidity is higher than outside (KLAR \& ALVES, 1996). Teodoro et al. (1986) showed that the evaporation were significantly higher outside than inside greenhouses, also using Class A Pan.

Table 3. Tukey Test for evaporation averages from blocks.

\begin{tabular}{lllll}
\hline & Block1 & Block 2 & Block 3 & Block 4 \\
\hline Evaporation $(\mathrm{mm})$ & $65.3997 \mathrm{c}$ & 68.8111 ba & $69.6906 \mathrm{a}$ & $66.30 .97 \mathrm{bc}$ \\
\hline
\end{tabular}

Same letters mean no differences between average values $(\mathrm{P}<0.05)$.

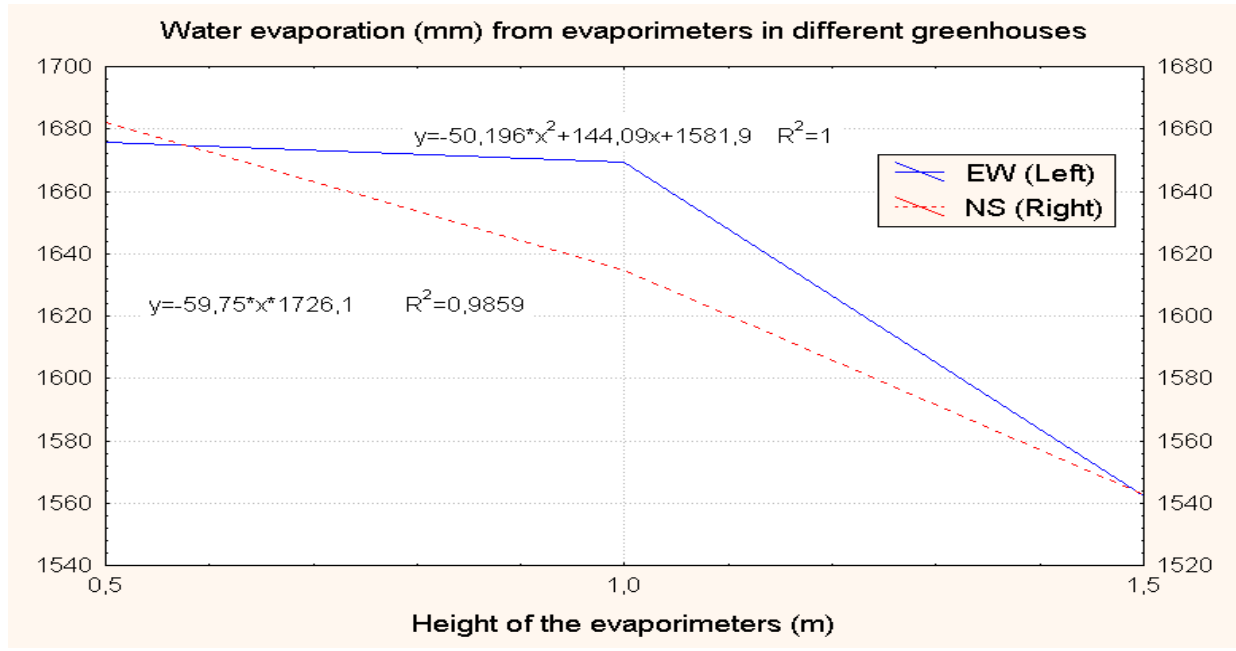

Figure 5. Water evaporation of the evaporimeters in EW and NS greenhouses. 
Table 4. Comparative test of the Class A pan evaporation average through Student-Newman-Keus Method

\begin{tabular}{lc}
\hline Environment & $\mathrm{P}<0.05$ \\
\hline Outside x NS greenhouse & $1.371^{*}$ \\
Outside x EW greenhouse & $1.167^{*}$ \\
EW x NS greenhouses & 0.204 n.s. \\
\hline
\end{tabular}

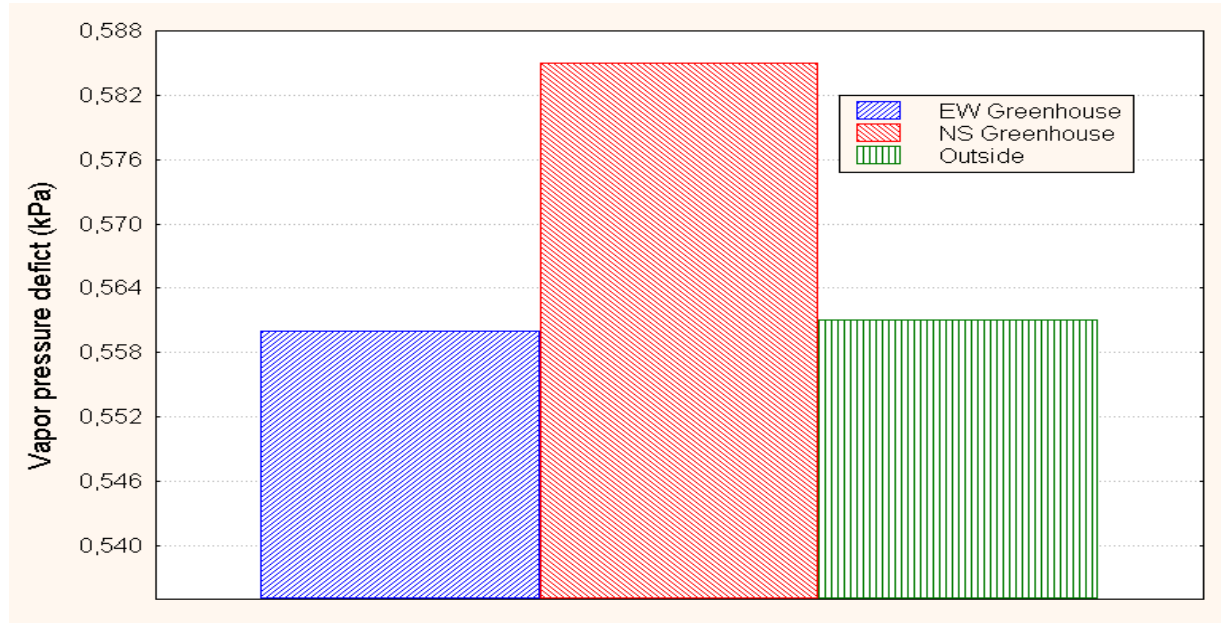

Figure 6. Vapor pressure deficit average values from $\mathrm{E} / \mathrm{W}$ and $\mathrm{N} / \mathrm{S}$ greenhouses and outside environments.

The Table 5 shows the fresh matter weight values obtained from the plants inside greenhouses. According Klar (1988), plants have the best conditions for development under favorable conditions of air temperature and humidity, soil water content and energy or radiation received. The plants from the beds which received more energy, according to the higher evaporations from the evaporimeters, showed the best performance in relation to productivity of fresh and dry matter of lettuce.

Table 5. Fresh matter plant production averages for blocks inside greenhouses.

\begin{tabular}{lcccc}
\hline & Block 1 & Block 2 & Block 3 & Block 4 \\
\hline Fresh Matter & $423.79 \mathrm{ab}$ & $442.08 \mathrm{a}$ & $444.44 \mathrm{a}$ & $370.04 \mathrm{~b}$ \\
\hline
\end{tabular}

Same letters mean no differences between blocks for Tukey Test $(\mathrm{P}<0.05)$.

\section{CONCLUSIONS}

There were not variability for evaporations obtained from evaporimeters through applied geostatistic use on the spatial data distribution.
The minimum air temperature average from inside greenhouses were lower than outside values.

The horizontal and vertical profiles of evaporation values from both greenhouses showed decreases with the higher positions of the evaporimeters. 
The highest lettuce productivity occurred on the beds that showed the highest evaporations and, consequently, the highest radiation reception.

\section{ACKNOWLEDGEMENTS}

The authors acknowledge Charles Duruoha and Gilberto Winckler for helping the English translation and the field labors, respectively.

\section{REFERENCES}

BOULARD, T. et al. Performance of greenhouse heating system with a phase change material. Agriculture and Forest

Meteorology, New York, v. 52, n.3, p. 303318, 1990.

BURIOL, G. A.; STRECK, N. A.; PETRY, C. Transmissividade à radiação solar do polietileno de baixa densidade utilizado em estufas. Ciência Rural, Santa Maria, v. 25, n. 1, p. 1-4, 1995.

EMBRAPA. Centro Nacional de Pesquisa de Solo. Sistema brasileiro de classificação de solos. Brasília: EMBRAPA, 1999. 399 p.

FILGUEIRA, F. A. R. Manual de

olericultura. São Paulo: Ceres, 1982. 357 p.
KLAR, A. E. A água no sistema solo planta atmosfera. 2. ed. São Paulo: Nobel, 1988. v. 1, $406 \mathrm{p}$.

KLAR, A. E.; ALVES, D. R. B.

Evapotranspiração de referência em um túnel plástico. In: SIMPÓSIO BRASILEIRO DE RECURSOS HÍDRICOS, 1996, Recife.

Anais... São Paulo: Associação Brasileira de Recursos Hídricos, 1996. v. 2, p. 179-183.

KLAR, A. E., BRAGA, M. B. Plastic tunnel postion and irrigation management of pepper plants (Capsicum annuum L) In:

INTERNATIONAL AGRICULTURAL ENGINEERING CONFERENCE, 2000, Warwick. Proceedings... Warwick: University of Warwick, 2000. p. 120-124.

MOSS, G. I. Et al. A technique for accurately measuring water use by entire greenhouse crops. Horticulture Science, Alexandria, v. 20, n. 3, p. 887-879, 1985.

OLIVEIRA, M. R. V. O emprego de casas de vegetação no Brasil: vantagens e desvantagens.

Pesquisa Agropecuária Brasileira, Brasília, v. 30, n. 8, p. 1049-1060, 1995.

RAIJ, B.van; CANTARELLA, H.; QUAGGIO, J. A.; FURLANI, A. M. C. Recomendações de adubação e calagem para o Estado de São Paulo. Boletim Técnico do Institulo Agronômico, Campinas, n. 100, p. 1-285, 1996.

TEODORO, R. E. F.; OLIVEIRA, A. S.; MINAMI, K. Efeitos da irrigação por gotejamento na produção de pimentão (Capsicum annuum L.) em casa de vegetação. Ciência Agrícola, Piracicaba, v. 50, n. 2, p. 237-243, 1993. 